\title{
Anal abnormalities in childhood myotonic dystrophy-a possible source of confusion in child sexual abuse
}

\author{
W Reardon, H E Hughes, S H Green, V Lloyd Woolley, P S Harper
}

\begin{abstract}
Myopathic involvement of the perianal musculature is one of the less well recognised features of myotonic dystrophy in children and may present with physical signs suggestive of sexual abuse. Details of six children with myotonic dystrophy are presented to emphasise the importance of considering an underlying myopathic condition in the differential diagnosis of anal laxity.
\end{abstract}

Involvement of smooth, as well as striated, muscle in the pathological processes of myotonic dystrophy is well recognised and may give rise to important symptoms, especially when involving the oesophagus or colon. ${ }^{12}$ Abnormalities of anal sphincter and rectal pressure, documented in adult patients with myotonic dystrophy, are likely to reflect such pathological changes in the external and internal anal sphincter muscles. ${ }^{34}$ The interplay of several pathological mechanisms, including muscle atrophy, myopathy, and neural disturbance is suggested as the basis of these anal sphincter changes by studies in adult patients with myotonic dystrophy. ${ }^{5}$ The present report suggests that similar changes may also be observed in children, in whom awareness of the possible implications of anal abnormalities may raise the suggestion of sexual abuse.

After recent referral of a child with the congenital form of myotonic dystrophy and anal abnormalities, in whom the possibility of sexual abuse had been inappropriately suspected, we have reviewed, the extensive records of children with myotonic dystrophy available to this department, and identified other instances of anal abnormalities in this patient group. We are aware of approximately 200 children with this muscle condition. However, clinical data are lacking in many instances as the family may have come to attention for DNA testing or advice on a particular clinical issue and not have been seen here. For these reasons it is difficult to quantify the patient base from which these other five cases have been drawn.

By emphasising the nature and range of these anal abnormalities, we hope to alert colleagues to this important muscular cause of anal sphincter dysfunction and so avoid confusion with anosexual abuse and the distress that related investigations will cause to families.

\section{Case reports}

Case 1 was a 14 year old girl with congenital myotonic dystrophy that had been diagnosed when she was 1 year old and had been referred for investigation of developmental delay. Her mother, in whom classical features of the adult form of the disease were observed, was also diagnosed as having the disease. The main features of the patient's condition were developmental delay, recurrent ear infections, and orthopaedic problems stemming from bilateral talipes at birth. Bowel habit was generally regular and her intermittent episodes of constipation were satisfactorily treated with laxatives.

During the course of a sex education class at the special needs educational establishment that she attended, the patient claimed to her teacher than she had had sexual relations with a male member of her family. Although this was not considered by staff or others to have a serious basis, there followed an investigation by a joint social services and police investigation team. Genital examination by this team showed no evidence to substantiate her claim. However, concern was expressed at her abnormally lax anus, which was felt by the police surgeon to be unrelated to her underlying muscle condition and more likely to be indicative of insertion of an object into the patient's anal canal. At examination the anal sphincter was dilated and floppy with faeces clearly visible in the rectum. A reflex dilation of the anus was
Institute of Medical Genetics, University Hospital of Wales, Heath Park, Cardiff CF4 4XN

W Reardon

H E Hughes

P S Harper

The Children's Hospital, Birmingham

S H Green

Ysbyty Gwynedd, Bangor

V Lloyd Woolley

Correspondence to:

Dr Reardon.

Accepted 22 November 1991

Accepted 22 November 1991

\section{Details of history and clinical signs in cases 1-6}

\begin{tabular}{|c|c|c|c|c|c|}
\hline $\begin{array}{l}\text { Case } \\
\text { No }\end{array}$ & Sex & $\begin{array}{l}\text { Age at } \\
\text { presentation } \\
\text { (years) }\end{array}$ & Presenting history & Attempted management & Anal signs \\
\hline 1 & $\mathbf{F}$ & 14 & Intermittent constipation & Laxatives & $\begin{array}{l}\text { Anal sphincter laxity, } \\
\text { reflex dilatation }\end{array}$ \\
\hline 2 & $\mathbf{F}$ & 15 & Lifelong faecal soiling & - & $\begin{array}{l}\text { Appreciable anal sphincter } \\
\text { laxity (figure) }\end{array}$ \\
\hline 3 & $\mathbf{M}$ & 18 & Episodic diarrhoea & Behaviour modification & $\begin{array}{l}\text { Anal sphincter laxity, } \\
\text { anal margin inflammation }\end{array}$ \\
\hline 4 & $\mathbf{F}$ & 12 & Daily incontinence & $\begin{array}{l}\text { Loperamide and } \\
\text { metoclopramide }\end{array}$ & Anal laxity \\
\hline 5 & $\mathbf{M}$ & 8 & Episodic incontinence & Dietary & $\begin{array}{l}\text { Anal sphincter laxity, } \\
\text { anal margin inflammation }\end{array}$ \\
\hline 6 & $\mathbf{F}$ & 8 & Occasional incontinence & $\begin{array}{l}\text { Behaviour modification, } \\
\text { loperamide }\end{array}$ & $\begin{array}{l}\text { Anal sphincter laxity, } \\
\text { perianal inflammation }\end{array}$ \\
\hline
\end{tabular}




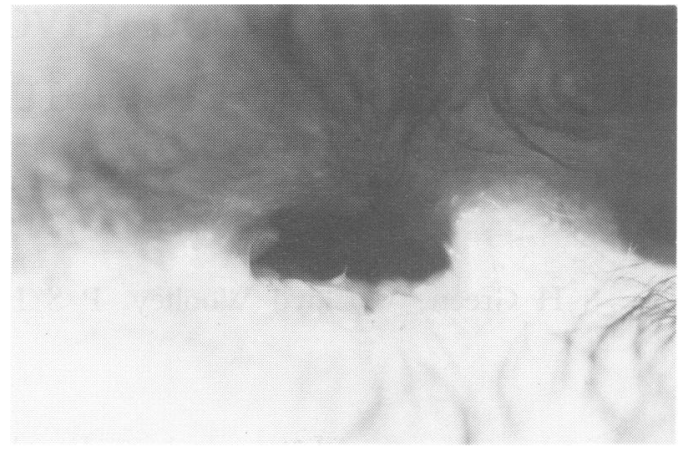

Anal sphincter laxity in case 2.

observed on parting the buttocks. After confirmation that similar features had been observed in other children with myotonic dystrophy, the investigation was closed and the male family member fully exonerated.

Details of five other cases are presented in the table; anal sphincter laxity for case 2 is shown in the figure.

\section{Discussion}

The interpretation in children of physical signs consistent with sexual abuse is a difficult area for clinicians. Moreover, the distressing consequences for families of misinterpretation of physical signs as evidence of sexual abuse demand that any such signs as do exist are accurately interpreted. While it is acknowledged that a significant number of sexually abused children have no abnormal physical findings, there is also a recognition that very few signs are diagnostic of abuse. ${ }^{6}$ In view of our ignorance of the pathophysiology of the anal canal, it is especially difficult to weigh the significance of anal signs in relation to possible sexual abuse. ${ }^{7}$
This report highlights anal signs of sphincter laxity, reflex anal dilatation, perianal inflammation, and faecal soiling in children with myotonic dystrophy and underlines the significant management challenge that attends these problems. A diagnosis of sexual abuse was entertained in two cases, leading in both to a social services and police joint investigation, with obvious distress to the families involved. In both instances the weight of evidence in favour of sexual abuse revolved around the anal signs.

The uncertainties inherent in interpreting the physical signs of sexual abuse are readily acknowledged, as is the principle that such examination and interpretation will be best performed by those with a particular expertise in the field. However, in view of the physical signs reported in this series of patients, a useful caveat to those charged with so onerous a responsibility might be to beware of the possibility of misleading anal signs in children with unexplained developmental delay and in conditions which can lead to disturbances in muscle tone. Recognition of these alternative causes of anal abnormalities may help avoid the trauma of sexual abuse investigation in some families.

1 Harper PS. Myotonic dystrophy. 2nd Ed. London: WB Saunders, 1989.

Schuman BM, Rinaldo JA, Darnley JD. Visceral changes in myotonic dystrophy. Ann Intern Med 1965;63:793-9.

3 Schuster MM, Tow DE, Sherbourne DH. Anal sphincter abnormalities characteristic of myotonic dystrophy. Gastroenterology 1965;49:641-8.

4 Hamel RJ, Devroede G, Arhan P, Tetreault JP, Lemieux B, Scott $\mathrm{H}$. Functional abnormalities of the anal sphincter in patients with myotonic dystrophy. Gastroenterology 1984; 86:1469-74.

5 Eckardt VF, Nix W. The anal sphincter in patients with myotonic muscular dystrophy. Gastroenterology 1991;100: 424-30.

6 Royal College of Physicians. Physical signs of sexual abuse in children. London: Royal College of Physicians, 1991.

7 Priestley B, Hull D. Interpreting the signs of sexual abuse of children. $\mathcal{F} R$ Coll Physicians Lond 1991;25:84-6. 